\title{
Saladin: The Animated Series sebagai WACANA ORIENTALISME
}

\author{
Izra Inna Md Idris \\ Universiti Malaya \\ izrainna@gmail.com \\ Mohamad Saleeh Rahamad @ Ahamad \\ Universiti Malaya \\ saleeh@um.edu.my \\ Md Azalanshah Md Syed \\ Universiti Malaya \\ azalan@um.edu.my
}

\section{ABSTRACT \\ SALADIN: THE ANIMATED SERIES AS DISCOURSE OF ORIENTALISM}

This article analyzes the discourse of Orientalism in Saladin: The Animated Series for the first episode entitled Rising Star. Edward Said (1978) in his book Orientalism: Western Conceptions of the Orient (1978) opposed Western perspectives on the East and analyzed postcolonial literary works in historical and social contexts, and describes orientalist discrimination in speculating and specifying data sources for particular interests. This study draws on a series of animations directed by Steve Bristow that showcased the leading Islamic figure of the crusade, Sultan Salahuddin al-Ayubi (1137-1193) or known as Saladin by the Western world. Taking the personality of an Islamic character to be the main character in the animated series is something to be proud of, but the fact about Sultan Salahuddin al-Ayubi's personality has been distorted in Saladin's character. This study looked at the orientalist attacks on the personality of Sultan Salahuddin al-Ayubi and found that the Saladin's character was portrayed as physically weak, shallow-minded, and disobedient to his father. The whole of this first episode shows the misrepresentation of facts and the distortion of the image of Salahuddin al-Ayubi.

Keywords: orientalism, post-colonial, Saladin, misrepresentation, misinterpretation

\section{PENGENALAN}

Animasi di Malaysia telah bermula seawal tahun 1926 melalui wayang kulit, iaitu sejenis teater tradisional yang sangat popular di Tanah Melayu sekitar tahun 1920-an dan dikenali sehingga kini (Mohd Taib Osman, 1989). Wayang kulit ialah sejenis hiburan yang menggunakan 
cahaya dan bayang, manakala persembahan gerakan watak wayang kulit pula dikawal oleh dalang atau tok dalang melalui seni tangan, leher dan mulut yang digerak-gerakkan. Amin Sweeney (1972: 17) juga menyatakan bahawa di Malaysia wayang kulit dipentaskan di panggung dengan skrin berwarna putih dan diposisikan ke arah penonton. Lampu atau pelita diletakkan di belakang skrin putih tersebut dan Dalang memanipulasi boneka yang terletak di antara lampu dan skrin untuk menghasilkan bayang pada skrin sambil memulakan cerita. Pergerakan boneka oleh Dalang ini menyerupai teknik menggerakkan watak animasi..

Anker Rentse (1936: 284) menyatakan, The shadow play as found in Malaya is very ancient form of entertainment. Menurutnya, wayang kulit yang ditemui di Tanah Melayu ialah karya hiburan yang berbentuk kuno. Gerakan ini memberi inspirasi untuk pembuatan animasi malahan gerakan ini menyamai teknik gerakan dalam pembikinan watak kartun animasi.

Filem animasi telah bermula di Malaysia (pada ketika itu dikenali sebagai Tanah Melayu) pada tahun 1946 oleh Mcff Sheperd (Hassan, 2003). Pada ketika itu sebuah unit filem yang dinamakan Unit Filem Malaya (kini dikenali sebagai Filem Negara) telah ditubuhkan bagi membantu filem animasi pendek. Filem animasi pendek yang pertama diterbitkan pada tahun 1978 di Malaysia ialah Hikayat Sang Kancil oleh Anandam Xavier dan telah ditayangkan di televisyen pada tahun 1983. Seterusnya filem pendek yang dihasilkan sekitar tahun 1984 sehingga 1987 ialah Sang Kancil \& Monyet, Sang Kancil \& Buaya, Gagak Yang Bijak, Arnab Yang Sombong dan Singa Yang Haloba (Hassan, 2008; Norizan, Leela Rajamani, \& Zuraidah, 2014).

Di Malaysia, produk animasi dua dimensi (2D) terlebih dahulu menguasai pentas kartun di layar perak. Antara produk animasi televisyen 2D di Malaysia ialah Usop Sontorian, Anak-anak Sidek, Kampong Boy, Kluang Man, dan Bola Kampung, manakala produk animasi 3D pula ialah Upin E Ipin, BoBoiBoy, Pada Zaman Dahulu, dan Dunia Eicak. Produk Filem animasi 2D di Malaysia ialah Kancil, Silat Lagenda dan Puteh, manakala produk filem animasi 3D pula ialah Geng Pengembaraan Bermula, Seafood, Bola Kampung, dan War of the Worlds: Goliath (Azran Fitri, 2008).

Pembabitan Koridor Raya Multimedia (Multimedia Super Corridor-MSC) dalam sektor animasi memberikan dampak terhadap peningkatan mutu animasi di Malaysia. Penerbitan siri animasi Upin E Ipin, Upin E Ipin dan Kawan-kawan, filem animasi 3D Geng Pengembaraan Bermula, Seafood, Boboiboy, Saladin: The Animated Series, Pada Zaman Dahulu, dan Bola Kampung, telah membuahkan hasil yang membanggakan negara. Siri animasi Upin E Ipin telah menjadi satu tarikan yang luar biasa di Malaysia dan di negara-negara jiran seperti Indonesia, Brunei, dan Thailand (Azran Fitri, 2008). Kejayaan animasi Upin E Ipin dengan inisiatif dan sokongan oleh MSC dan Perbadanan Pembangunan Multimedia (MDeC) merupakan hasil terbaik negara.

\section{SALADIN: THE ANIMATED SERIES}

Saladin: The Animated Series merupakan sebuah animasi yang mengambil watak sebenar Sultan Salahuddin al-Ayubi, yang merupakan seorang wira Islam, sultan dan penguasa, ketua pahlawan perang, anak kepada seorang gabenor, serta suami, dan bapa. Watak sebenar ini telah diambil dan ditukarkan menjadikan watak utama dalam siri animasi ini. Sultan Salahuddin al-Ayubi digeruni oleh pihak Kristian kerana penguasaannya kepada ilmu dan strategi perang yang tinggi dan baik, ketangkasannya berperang, kebaikan hatinya dan sifatnya yang merendah diri, kecintaannya kepada al-Quran dan jihad di jalan Allah. 
Kemenangan menakluki kembali Masjidil al-Aqsa dan tanah Palestin merupakan cita-cita dan impiannya (Beha Ed-Din, 1896; Syed Alwi, 2015).

Saladin: The Animated Series telah memulakan projeknya pada tahun 2004 dan merupakan siri animasi terbitan Malaysia pada tahun 2010. Siri ini telah mengambil masa selama enam tahun untuk disiapkan bagi tontonan umum. Pada permulaan pembikinannya pada tahun 2004, pihak penerbit merancang untuk menerbitkannya dalam bentuk filem, tetapi setelah perbincangan dijalankan dengan pihak pengurusan, filem yang menelan kos RM15 juta ini ditukar kepada siri animasi dengan judul Saladin: The Animated Series dengan kos yang sama (Abdul Aziz, 2011). Penerbitan siri animasi ini-yang mengandungi 26 episod, iaitu 14 episod siri pertama dan 12 episod siri kedua-merupakan usaha sama Perbadanan Pembangunan Multimedia (MDeC) dan Al-Jazeera Children Channel (AJCC). Animasi ini diterbitkan dalam tiga bahasa, iaitu bahasa Inggeris, bahasa Arab, dan bahasa Malaysia dalam genre fiksyen sejarah. Siri animasi ini telah ditayangkan pada saluran Nasional 1 Televisyen Malaysia (TV1) pada September 2010.

Saladin: The Animated Series telah diarahkan oleh Steve Bristow, pengarah dari Australia, dengan menggunakan 95\% kepakaran pereka animasi dari Malaysia. Bristow telah memperlihatkan kefahamannya tentang sumber naratif ini dalam kenyataan yang berikut:

Saladin is an animated project inspired by the life of Salah Al-Din Yusuf Ibni Ayyub, the Islamic hero who united Muslims in the holy war against the Crusaders in the $12^{\text {th }}$ century.

(Bristow, September 2010)

Dalam portal rasmi Saladin: The Animated Series, pihak penerbitan menyatakan bahawa projek animasi ini diilhamkan daripada kehidupan Salah al-Din Yusuf Ibni Ayyub atau lebih dikenali sebagai Sultan Salahuddin al-Ayubi oleh masyarakat Islam di dunia. Oleh yang demikian, dapat difahami bahawa sebarang bentuk pewacanaan yang dilakukan oleh penerbit adalah dalam keadaan sedar atau niat yang terancang. Makalah ini akan melihat "niat" atau agenda mereka berdasarkan manipulasi sejarah yang difiksyenkan dalam animasi ini.

\section{ULASAN PERSURATAN}

Kajian orientalis tentang Islam dan sejarahnya adalah sangat terperinci dan teknikal sehingga menyebabkan pembaca awam tidak memahami implikasi negatifnya. Kedua-dua buah buku yang ditulis oleh Edward Said, Orientalisme: Western Conceptions of the Orient (1978) dan The World, The Text and the Critic (1983) menerangkan diskriminasi pihak orientalis dalam menentukan spekulasi dan penentuan sumber data bagi kepentingan tertentu. Kajian wacana orientalis juga meliputi kajian sejarah, linguistik, teori ras, filosofi, antropologi, malahan biologi, bermula dari abad ke-19 lagi (Said, 1983: 4).

Menurut Said (1978: 203), Orientalisme ialah kajian mengenai Orient, iaitu Timur, oleh orang Barat dari segi ketamadunan, orang, dan kawasan. Said telah membuat kajian berkenaan kebencian Barat terhadap dunia Timur berasarkan perspektif misrepresentation dan misinterpretation terhadap agama Islam dan tokoh-tokoh Islam. Menurutnya, pihak orientalis tidak dapat menyerang fakta sejarah berkenaan kredibiliti tokoh Islam Sultan Salahuddin al-Ayubi menawan Palestin tanpa menumpahkan darah, tetapi mereka dapat 
menyerang kredibilitinya semasa kecil dan remaja secara tekstual dengan tujuan mengubah dan merendah-rendahkan tokoh Islam ini.

Penyelewengan ini berlaku bagi "menyerang" semula bakti yang telah ditaburkan oleh Sultan Salahudin kepada masyarakat Palestin, Mesir dan lebih-lebih lagi pihak Kristian dalam Perang Salib. Salahuddin al-Ayubi ialah tokoh Islam yang berjaya memenangi kembali Baitul Maqdis tanpa peperangan (Mohd Roslan \& Nor Shakila, 2012). Ini telah memberi tamparan yang sangat hebat kepada pihak gereja di London pada ketika itu.

Perang Salib memakan masa yang lama, iaitu dari 1096 sehingga 1291 Masihi dengan tujuh siri peperangan (Mohd Roslan \& Nor Shakila, 2012: 62). Salahuddin al-Ayubi ialah panglima yang paling banyak memimpin gerakan tentera Islam dalam memerangi tentera Salib. Kenyataan ini tidak menggembirakan hati pihak orientalis, lalu mereka menggunakan pelbagai cara untuk merendah-rendahkan tokoh pahlawan ini. Sekiranya mereka tidak berjaya mengubah sejarah kemenangan pihak Islam ke atas Jerussalem dan ketokohan Sultan Salahuddin al-Ayubi, cara jalan yang halus untuk menjatuhkan kredibiliti Salahuddin alAyubi adalah melalui waktu zaman mudanya; zaman kanak-kanak, dan zaman remajanya.

Antara kajian lepas yang berkaitan orientalisme ialah 'Orientalisme Kolonial dalam Kisah Pertualangan Mowgli dalam novel The Jungle Book karya Rudyard Kipling: Tinjauan Pascakolonialisme'. Kajian ini meneliti unsur pencitraan orientalis dengan perspektif pascakolonial berdasarkan teori Orientalism oleh Edward Said. Pengumpulan data dilakukan dengan teknik close reading, dan data yang dianggap relevan didokumentasikan. Metode analisis data dilakukan dengan melihat teks, iaitu meneliti naratif rasional berdasarkan perdebatan yang terdapat dalam teori pascakolonial. Citra Orientalisme dilihat berdasarkan watak dan perwatakan, dan latar dalam karya tersebut.

Kajian ini menganalisis citra Timur dalam novel The Jungle Book daripada dua perspektif: 1) dunia Timur, dan 2) geografi imaginatif. Said berpandangan bahawa cara Barat melihat representasi kebudayaan Timur dalam novel tersebut adalah tidak tepat, kerana ideologi Orientalisme yang digunakan oleh Balfour, Cromer, dan Kissinger yang menyifatkan dunia Timur sebagai tidak memiliki sifat rasional, tidak cinta pada kedamaian, bersifat liberal, tidak logik, tidak memegang nilai murni, dan tidak berasa curiga. Dalam geografi imaginatif, Said melihat karya Dante, Inferno, yakni cara pandang Orientalis yang menempatkan Timur sebagai objek yang dapat disesuaikan dengan cara berfikir orang Barat yang subjektif (Imam Hendra Saputra, 2015: 2-3).

Kajian orientalisme seterusnya ialah 'Representasi Orientalisme dalam Film: Analisis Semiotik Mengenai Representasi Orientalisme dalam Film Black Hawk Down' arahan Ridley Scott (2001). Menurut kajian ini, hampir semua filem Barat, terutamanya filemfilem Hollywood, seringkali menggambarkan masyarakat Timur terkebelakang dengan kebudayaannya yang ketinggalan apabila dibandingkan dengan Barat. Konstruksi yang berkembang di Barat menganggap masyarakat dan kebudayaan Timur memiliki kedudukan yang lebih rendah daripada masyarakat dan kebudayaan Barat. Pandangan Orientalisme ini mempengaruhi dan menguasai media massa seperti filem, khususnya, dan masyarakat Barat secara amnya.

Kajian orientalisme ini membuat analisis semiotik dalam tiga peringkat, iaitu realiti, representasi, dan ideologi dalam filem Black Hawk Down. Filem ini telah menampilkan Amerika sebagai "hero" bagi negara lain terutamanya di Timur. Filem produksi Hollywood ini menunjukkan negara Barat adalah maju, rasional, dan penuh dengan kemanusiaan 
serta mempunyai kekuatan ketenteraan yang terbaik. Dalam filem ini, 18 tentera Amerika digambarkan dengan penuh heroik menewaskan 1000 orang Somalia dalam pertempuran Mogadishu (Fauzia, 2007: 54-55).

Walaupun dua kajian di atas menggunakan wacana Orientalisme sebagaimana dalam kajian ini, kajian ini membincangkan penyelewengan fakta dan perlecehan tokoh Islam, Salahuddin al-Ayubi oleh pengarah orientalis Steve Bristow yang telah merosakkan imej Salahuddin al-Ayubi dalam siri pertama Saladin: The Animated Series - Rising Star.

\section{KAEDAH KAJIAN}

Analisis tekstual terhadap Saladin: The Animated Series ini menggunakan perspektif Orientalisme, iaitu misrepresentation dan misinterpretation. Analisis dilakukan terhadap bingkai daripada tiga episod dalam siri pertama Saladin: The Animated Series - Rising Star.

Penelitian dilakukan pada latar, watak dan perwatakan. Bagi pembahagian latar, aspek latar masa dan latar tempat serta perubahan yang dilakukan akan dijadikan bahan penelitian. Seterusnya, untuk watak dan perwatakan, kajian dilakukan ke atas watak utama, Saladin, Anisa, dan Tarik, serta watak sampingan, iaitu Omar, Bapa, Ibu, Shahan (abang Saladin), dan Tuan Mustafa (majikan Saladin) di samping perubahan yang dilakukan oleh orientalis.

\section{DAPATAN KAJIAN DAN PERBINCANGAN Pengarah Saladin: The Animated Series: Rising Star}

Dalam sesebuah produksi animasi, pengarah ialah orang yang bertanggungjawab mengemudikan keseluruhan penceritaan. Halas dan Manvell (1970: 214) turut menyatakan perkara yang sama: ... the producer is normally also the director and possibly the key animator as well. Menurut mereka, produser animasi selalunya adalah pengarah dan juga merupakan animator utama bagi sesebuah animasi.

Stephen Bristow merupakan pelabur asing bagi kandungan kreatif di Malaysia dengan kerjasama MDeC dan syarikat animasi tempatan. Dilahirkan dan dibesarkan di Melbourne, Australia Bristow telah mendapat pendidikan awal di Melbourne, seterusnya berjaya mendapat Diploma dalam bidang Produksi Media dari Victoria College di Melbourne. Seterusnya, beliau mengeluarkan animasi secara profesional di bawah produksinya Professional Animation Production selama lebih 20 tahun. Produksinya juga menawarkan studio perkhidmatan animasi di Asia (Bristow, 2013).

Sementara itu, orientalis ialah orang Barat atau orang asing yang mengambil Islam sebagai subjek penyelidikan atau bahan kajian, juga mengambil sejarah tokoh Islam dan menukarnya dalam bentuk animasi. Dua usaha yang dilakukan oleh pihak orientalis dalam siri animasi ini: pertama, menukar keperibadian Salahuddin al-Ayubi sewaktu kanak-kanak dan remaja, dan kedua, memasukkan maklumat yang salah dalam pemikiran kanak-kanak dalam lingkungan umur 10 hingga 12 tahun.

Gambar 1 menunjukkan bingkai awal Saladin: The Animated Series yang menerangkan bahawa animasi ini dihasilkan di Malaysia, di bawah MDeC dengan usaha sama al-Jazeera Children's Channel Co-Production. Bristow terlibat secara langsung dalam pembikinan siri animasi ini secara keseluruhannya, dan merupakan pengarah untuk episod 1, 2, 3, 4, 6, 8, 10; Penyunting Cerita (Story Editor) untuk episod 1, 2, 3, 4, 5, 6, 7, 8, 9, 10, 11, 12, 15, 16, 
dan 18 dan Penyelia Papan Cerita (Storyboard Supervisor) untuk episod 1,2,4,5,6,7,8,10 dan 12. Bristow telah terlibat secara keseluruhannya, sebagai pengarah, penyunting cerita, dan penyelia papan cerita untuk siri pertama Rising Star ini.

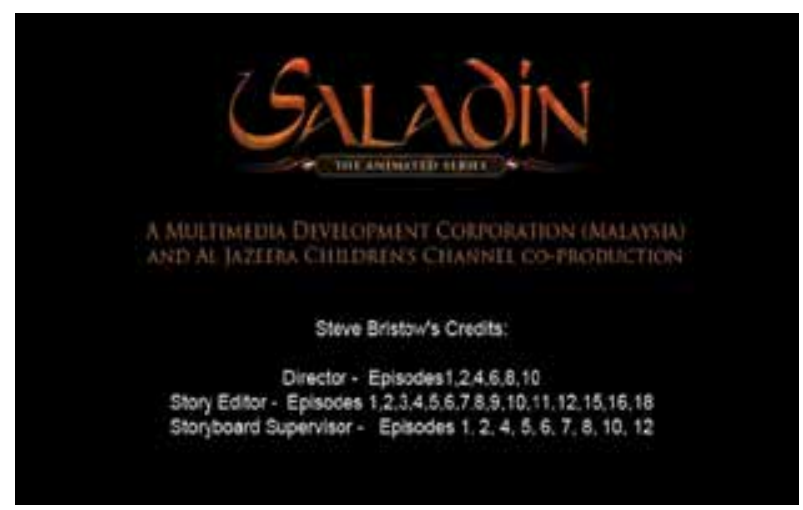

Gambar 1: Tajuk, Pengarah, Penyunting Cerita, Penyelia Papan Cerita Saladin: The Animated Series

\section{Watak Saladin dalam Saladin The Animated Series: Rising Star}

Siri pertama Saladin: The Animated Series - Rising Star atau 'Bintang yang semakin terserlah' mengisahkan Salahuddin al-Ayubi sewaktu berumur lapan tahun. Antara watak utama yang diperkenalkan pada usia muda ini ialah Saladin, Tarik, dan Anisa. Watak sampingan yang terdapat dalam siri pertama ini ialah Omar (penglipur lara), bapa Saladin (Najmudin Ayyub), ibu Saladin, Shahan (abang Saladin), Tuan Mustafa, dan Darwish.

\section{Latar masa dan tempat}

Saladin: The Animated Series ini mengambil latar masa tahun 1148 dan tempatnya adalah di Damsyik. Pemalsuan telah bermula pada bingkai ini kerana Salahuddin al-Ayubi sebenarnya dilahirkan di Tikrit pada tahun 1137 (Beha Ed-Din, 1896: 4; Lane Poole, 1906: 6; Syed Alwi, 2015:3) dan pada tahun 1148H, Salahuddin sudah berusia 11 tahun. Namun begitu, dalam Saladin: The Animated Series, Saladin baru berusia lapan tahun. Dari segi latar tempat pula Saladin membesar di Ba'albek sehingga berusia sembilan tahun (Syed Alwi, 2015:16), namun latar tempat yang diambil dalam siri animasi ini ialah Kota Damsyik. Oleh itu, pemalsuan fakta telah berlaku pada latar masa dan tempat dalam Saladin: The Animated Series.

\section{Perwatakan Saladin yang Digambarkan Anak Jalanan dengan Penggunaan Kata yang Kesat}

Pada awal cerita, Saladin dan teman karibnya, Tarik, sedang bermain pedang kayu, dan suara latar si penglipur lara, Omar sedang menceritakan perihal pahlawan agung.

Omar : $\quad$ The people tells story of the great warrior that one day will...

(Orang ramai bercerita tentang pahlawan agung yang suatu hari nanti akan...)

Tarik melarikan diri dari Saladin.

Saladin : $\quad$ Aaa... you'll never catch me... 
(Aaa... Kamu tidak akan dapat menangkap saya...).

Tarik berlari melimpasi Omar (seorang penglipur lara) yang pada ketika itu sedang bercerita kepada kanak-kanak di Kota Damsyik.

Tarik : Hi Omar...

Tarik menyapa Omar, yang pada ketika itu sedang bercerita pada kanak-kanak. Omar lalu menyapa kembali dengan berkata:

Omar : Tarik...

Saladin yang mengejar Tarik.

Saladin : Don't run you cowardly dog

(Jangan lari kamu anjing yang pengecut.)

Saladin berlari melimpasi tempat yang sama lalu menyapa Omar.

Saladin : Hi Omar...

Omar pun menyapa kembali.

Omar : Salahuddin...

Saladin terus berteriak ke arah Tarik.

Saladin : Plead before my blade...'

(Merayulah, sebelum pedang saya...)

Pada babak awal ini personaliti Salahuddin diserang oleh orientalis dengan penggunaan kata-kata kesat terhadap sahabat baiknya, Tarik. Perkataan '... you cowardly dog...' atau 'kamu anjing yang penakut' adalah kasar untuk dikatakan oleh seorang sahabat kepada sahabatnya walaupun semasa bermain. Pengarah orientalis cuba menjatuhkan kredibiliti Salahuddin al-Ayubi dengan menunjukkan kerendahan peribadi watak Saladin yang bermain-main di pasar tanpa kawalan dan melontarkan kata-kata kesat.

Pihak orientalis ingin menunjukkan bahawa dari kecil Saladin ini hanya orang biasa yang tiada keistimewaan malahan baginda lebih teruk berbanding orang biasa. Namun begitu, dalam catatan sejarah Salahuddin merupakan anak pembesar dan dibesarkan di istana serta dikasihi oleh Imaduddin Zanki (penguasa Mosul pada ketika itu) sejak lahir sehingga baginda berusia dua tahun sebelum ayahandanya berpindah ke Ba'albek setelah dilantik sebagai gabenor oleh Imaduddin Zanki (Beha Ed-Din, 1896: 4; Alwi, 2015: 15). Oleh itu, tidak mungkin anak seorang pembesar berlari dan bermain-main di pasar tanpa pemerhatian dan pengawasan daripada pengawal atau orang dewasa.

Pemalsuan yang lebih besar terpapar pada watak penglipur lara, Omar. Ketika umur Saladin lapan tahun, Omar mendapat firasat bahawa akan datang seorang pahlawan agung, namun gambaran Omar tidak menunjukkan watak seorang pahlawan agung. Dalam dialog di atas, Omar bercerita pada kanak-kanak di pasar: "Orang ramai bercerita tentang pahlawan agung yang suatu hari nanti akan ..." dan kata-katanya terhenti oleh sapaan Tarik dan Saladin. Omar meneruskan ceritanya, "Apa yang saya cakap tadi? Ya, seorang pahlawan agung..." Sementara itu, kelihatan Salahuddin berlari-lari mengejar Tarik dengan pedang kayu. Inilah yang cuba digambarkan oleh pihak produksi, iaitu pahlawan agung yang tidak memiliki ciri-ciri kepahlawanan. Akhirnya, cerita Omar itu tidak diteruskan oleh pengarah tetapi memasuki babak baharu. 


\section{Pembentukan Karakter Saladin dan Anisa Sewaktu Berusia Lapan Tahun}
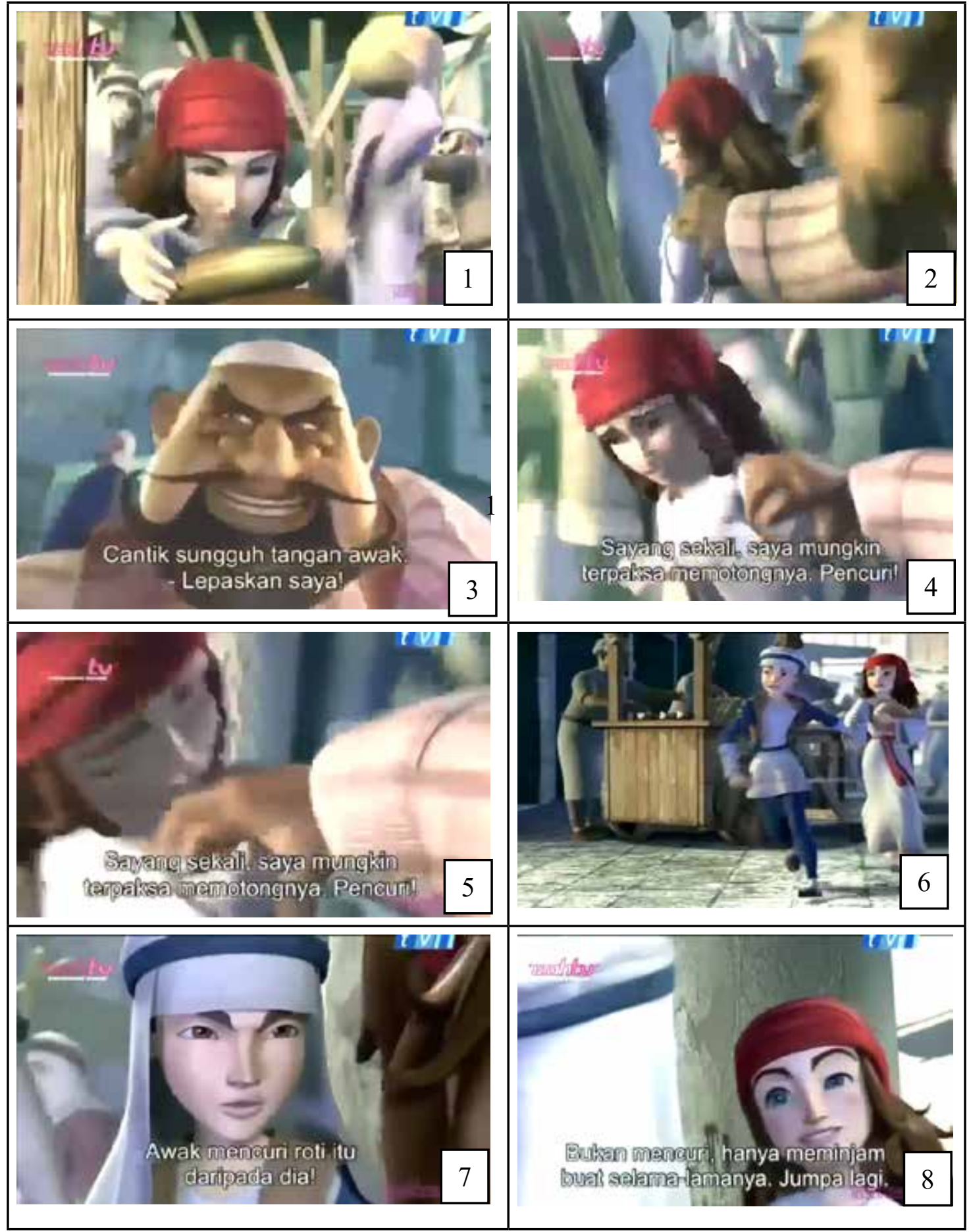

Gambar 2: Saladin dan Anisa semasa berusia lapan tahun

(01:13-03:35 di Animated_Stories_of_Islam.nashbooky.com.mp4) 
Bingkai-binkai di atas menunjukkan watak Salahuddin atau Saladin bersama Anisa sewaktu berumur lapan tahun, dan Anisa memegang sebuku roti yang dicuri daripada penjual roti. Pada babak ini Saladin cuba menyelamatkan Anisa daripada Si Penjual Roti. Terdapat dua penyelewengan (distortion) oleh pengarah orientalis dalam babak ini: pertama, Saladin bersentuhan dengan Anisa yang bukan muhrim semasa menyelamatkan Anisa (lihat bingkai 6). Pihak produksi meneruskan perlakuan bersentuhan ini sehingga Saladin dan Anisa berusia 18 tahun dalam siri ke-12. Walaupun Saladin hanya berusia lapan tahun, bukan suatu kebiasaan untuk seorang kanak-kanak lelaki bersentuhan dengan kanak-kanak perempuan apabila latar cerita ini berlaku di Damsyik, Syria.

Penyelewengan kedua, Saladin menyelamatkan seorang pencuri daripada mangsa kecurian. Sekali lagi pengarah orientalis ini melanjutkan perlakuan mencuri oleh watak Anisa ini sehingga dewasa. Babak ini memutarbelitkan keadaan yang dianggap cemas dengan menyerang hukum agama Islam yang suci daripada sentuhan lelaki dan perempuan yang bukan muhrim sebagaimana hadis yang diriwayatkan daripada Ma'qil bin Yasar (r.a) beliau berkata bahawa Rasulullah (S.A.W) bersabda: "Sekiranya dicucuk kepala salah seorang daripada kamu dengan jarum daripada besi, nescaya itu lebih baik buatnya berbanding dia menyentuh seorang wanita yang tidak halal baginya (bukan mahram)" (Riwayat alThabrani, Mu'jam Al Kabir (20/211) dlm. Muhammad Fu'ad Abdul Baqi, 2017). Babak ini juga menyerang hukum mengambil hak orang tanpa kebenaran. Surah al-Baqarah ayat 188 menyatakan yang mafhumnya:

Dan janganlah sebahagian kamu memakan harta sebahagian yang lain di antara kamu dengan jalan yang bathil dan (janganlah) kamu membawa (urusan) harta itu kepada hakim, supaya kamu dapat memakan sebahagian daripada harta benda orang lain itu dengan (jalan berbuat) dosa. Padahal kamu mengetahui.

Beha Ed-Din, atau lebih dikenali sebagai Ibn Shaddad, seorang kadi dari Aleppo pada zaman Salah ed-Din Yusuf Ayyub atau Salahuddin al-Ayubi, merupakan penulis pertama biografi Salahuddin dalam buku yang telah diterjemahkan ke dalam bahasa Inggeris bertajuk The Life of Saladin (Beha Ed-Din, 1896:xiii). Menurut Beha Ed-Din, Salahuddin al-Ayubi dilahirkan dalam keluarga yang dihormati: Salah ed-Din (Saladin) was the son of Ayub and grandson of Shadi, a Rawadiya Kurd of the great Hadaniya tribe (Beha Ed-Din, 1896: xv). Salahuddin ialah anak kepada Ayub dan cucu kepada Shadi, daripada bangsa Rawadiya Kurd, suku Hadaniya yang terbilang. Sebagai seorang anak dan cucu golongan bangsawan, penguasa, pentadbir kawasan, serta dikenali ramai, kehidupannya tentulah dipenuhi aktiviti penambahan ilmu, penghafalan al-Quran, bukannya bermain-main di pasar tanpa kawalan. Oleh yang demikian, wacana Orientalisme ini jelas untuk merendah-rendahkan kredibiliti bapanya sebagai seorang pentadbir, dan penguasa dalam mendidik anak, malahan merendah-rendahkan status Salahuddin al-Ayubi sebagai Sultan Mesir pada zaman itu.

\section{Watak dan Perwatakan Anisa sebagai Kekasih Saladin}

Salah satu serangan pihak orientalis dalam Saladin: The Animated Series ini adalah melalui teman-teman Salahuddin. Anisa ialah salah seorang teman Salahuddin yang mempunyai perwatakan negatif, iaitu mencuri. Bingkai di atas memaparkan watak Anisa sewaktu berumur 18 tahun. Babak di pasar Damsyik ini memperlihatkan kehebatan Anisa mencuri sebuku roti dengan mudah sekali. Serangan Orientalisme berlaku dalam pembinaan watak Anisa yang sejak berumur lapan tahun sehingga 18 tahun masih meneruskan kegiatan 
sebagai pencuri di pasar Damsyik. Watak Anisa sebagai gadis gipsi yang mencuri sekadar suka-suka kemudiannya menjadi kekasih Salahuddin dalam siri yang kelima. Ini adalah satu rencana untuk menjatuhkan kredibiliti Salahuddin al-Ayubi dengan memaparkan persekitaran kawan-kawan dan kekasih yang melakukan kesalahan.

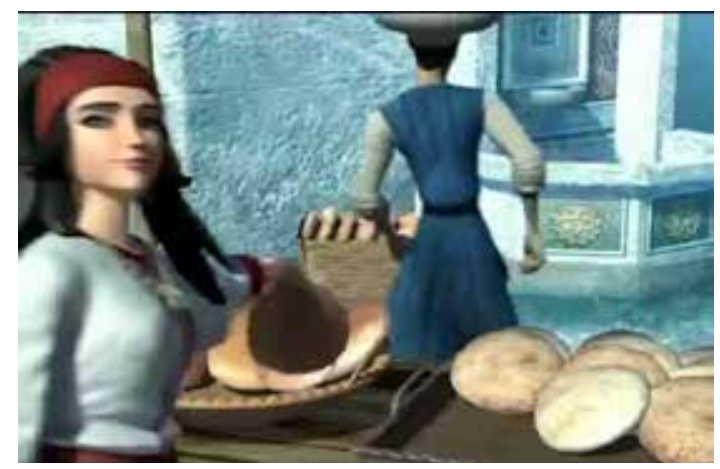

\section{Gambar 3: Anisa sedang mencuri roti di pasar Damsyik (08:56 di Animated_Stories_of_Islam.nashbooky.com.mp4)}

Secara tidak langsung, Orientalisme juga menyerang hukum Islam dalam babak ini. Dalam Islam, mencuri bermaksud mengambil sesuatu yang bukan haknya secara sembunyi tanpa pengetahuan pemiliknya dan hukumnya adalah haram. Damsyik terletak di Syria, sebuah negara Islam yang mengamalkan hukum Islam secara menyeluruh. Penjenayah mencuri akan dihukum potong tangan sekiranya didapati bersalah. Surah al-Maidah ayat 38 menyatakan yang mafhumnya:

Lelaki yang mencuri dan perempuan yang mencuri, potonglah tangan keduanya (sebagai) pembalasan bagi apa yang mereka kerjakan dan sebagai seksaan daripada Allah. Dan Allah Maha Perkasa lagi Maha Bijaksana.

Pihak produksi amat mengetahui hukum yang dijalankan di Damsyik kerana sewaktu Anisa mencuri roti pada usia lapan tahun, dia telah ditangkap oleh penjual roti. Penjual roti menuturkan dialog: "Cantik sungguh tangan awak. Sayang sekali, saya mungkin terpaksa memotongnya. Pencuri!". Kata-kata ini menunjukkan bahawa pengarah orientalis dan penulis skrip Choong Chi Ren seterusnya pihak produksi menyedari bahawa watak Anisa sedang melakukan kesalahan di Damsyik yang mengamalkan undang-undang Islam.

Babak ini juga memutarbelitkan keadaan sekali gus menghina agama Islam kerana hukuman memotong tangan seorang pencuri dalam Islam tidaklah semudah yang dituturkan dalam dialog skrip di atas. Menurut Paizah Haji Ismail (2008:24), untuk menjatuhkan hukun hudud menurut pandangan syariah Islam bukanlah mudah kerana penjenayah perlu melalui beberapa fasa "pembuktian" seperti pengambilan keterangan saksi, mengambil pengakuan, bukti keadaan (al-Qarinah), kenyataan pakar (al-Iqrar) sehingga dapat dibuktikan kebenarannya.

Bersembunyi di sebalik animasi dan kisah kanak-kanak, wacana Orientalisme ini telah mengubah jalan cerita kehidupan, seterusnya mengubah sistem pertahanan di Damsyik yang menjalankan hukum Islam secara menyeluruh dan meletakkan hukum sebagai sesuatu yang 
boleh dipermainkan. Pihak orientalis juga memperlihatkan kelemahan sistem pengawalan jenayah di Damsyik sehingga seseorang telah berjaya mencuri sejak berusia lapan sehingga 18 tahun dan masih tetap menjalankan kegiatan yang sama tanpa dapat diberkas oleh pihak berkuasa Damsyik.

\section{Perwatakan Peramal Omar}

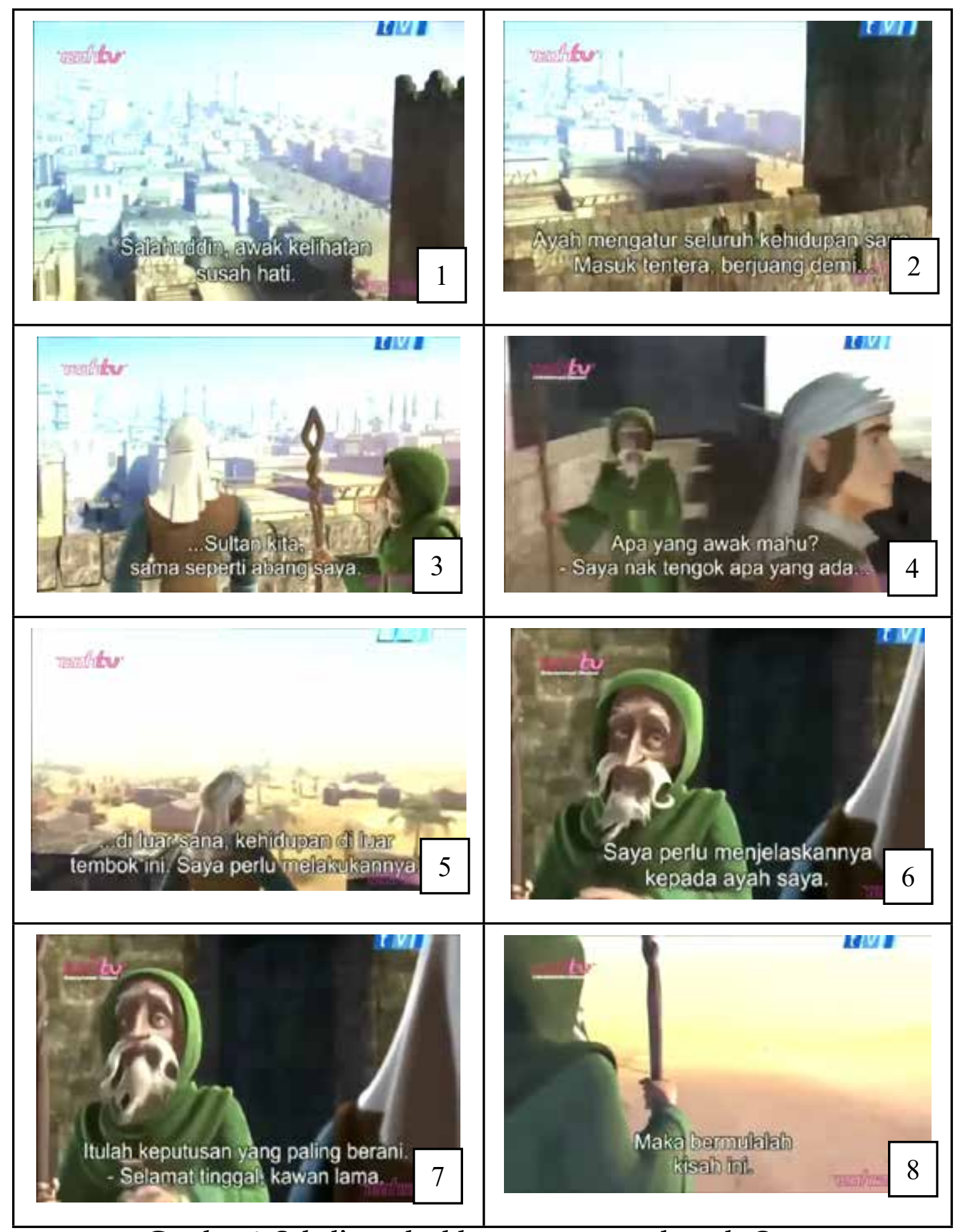

Gambar 4: Saladin meluahkan perasaannya kepada Omar (09:31-09:55; 24:51 di Animated_Stories_of_Islam.nashbooky.com.mp4) 
Lapan bingkai dalam Gambar 4 menunjukkan pertemuan antara Saladin dengan Omar. Omar merupakan penglipur lara atau pencerita untuk kanak-kanak di Damsyik, namun dia juga bertindak sebagai seorang peramal dalam hidup Saladin. Omar seolah-olah sudah nampak akan kehebatan Saladin. Bingkai pertama menunjukkan pertemuan Saladin dan Omar, dan Saladin meluahkan rasa tidak puas hati, sedih dan marah kepada Omar berkenaan bapanya. Dalam bingkai kedua dan ketiga, Saladin meluahkan rasa tidak puas hati terhadap bapanya yang telah mengatur seluruh kehidupannya seperti masuk tentera, dan berjuang demi Sultan seperti abangnya. Dalam bingkai keempat, Omar bertanya, apakah yang dikehendaki oleh Saladin dalam hidupnya. Dalam bingkai kelima dan keenam, Saladin menyatakan bahawa dia mahu mengembara melihat dunia di luar tembok Kota Damsyik. Bingkai ketujuh menunjukkan Omar menyokong tindakannya dengan menyatakan bahawa tindakannya ialah keputusan yang paling berani. Bingkai kelapan yang diambil sejurus Saladin meninggalkan Kota Damsyik memaparkan Omar yang berkata bahawa kisah Saladin ini bermula pada saat Saladin meninggalkan kota.

Dalam bingkai tersebut, terdapat serangan pihak orientalis terhadap peribadi Salahuddin al-Ayubi. Pertama, bingkai ini menunjukkan bahawa Salahuddin berfikiran cetek dengan tidak taat terhadap bapanya dan lebih mentaati peramal Omar, sedangkan Salahuddin al-Ayubi memandang tinggi bapanya, Najm ad-Din Ayyub yang merupakan penguasa di Ba'albek. Peramal Omar seolah-olah membenarkan tindakan tidak patuh Saladin terhadap bapanya dan menggalakkannya melakukan perkara menurut hati, iaitu keluar dari Damsyik, malahan meramalkan bahawa bermulanya kisah Saladin apabila dia meninggalkan kota Damsyik.

Penyelewengan seterusnya berlaku apabila Saladin dikatakan berjuang demi Sultan sedangkan tuduhan ini sangat buruk terhadap Salahuddin al-Ayubi kerana setiap orang Muslim berjuang demi Allah dan Rasulnya. Konsep jihad fi sabilillah atau jihad di jalan Allah bermaksud apa-apa sahaja amalan fizikal mahupun spiritual yang dibuat khusus untuk Allah. Jihad ialah peperangan suci melawan orang kafir kerana mempertahankan agama Islam (Mohamad Aminudin, 1988:9). Dalam memerangi musuh Allah atau musuh Islam, pihak muslim melancarkan perang untuk menegakkan yang hak (kebenaran) dan keadilan, dan menghancurkan atau melenyapkan kemungkaran. Antara kata Sultan Salahuddin yang dicatat oleh Ibnu Shaddad, To die in the way of God (Ibnu Shaddad: 27) atau "berperang untuk mati dijalan Allah". Perubahan dan pertukaran kecil yang dilakukan oleh orientalis, walaupun kecil, membawa kepada maksud yang besar untuk menukar persepsi umat kini terhadap tokoh Islam ini. Setiap bingkai yang dibawa oleh siri animasi ini tersasar daripada peribadi mulia Sultan Salahuddin al-Ayubi.

\section{Saladin: Tidak mentaati bapanya}

Sepuluh bingkai dalam Gambar 5 menunjukkan babak pertengkaran antara Saladin dengan bapanya, Najm ad-Din Ayyub. Bapanya meminta Saladin untuk membatalkan niatnya untuk bekerja dengan saudagar Mustafa dan terus berada di Damsyik untuk membantu tentera Islam memerangi tentera Frank yang dikhuatiri akan bertambah dalam peperangan yang akan datang. 


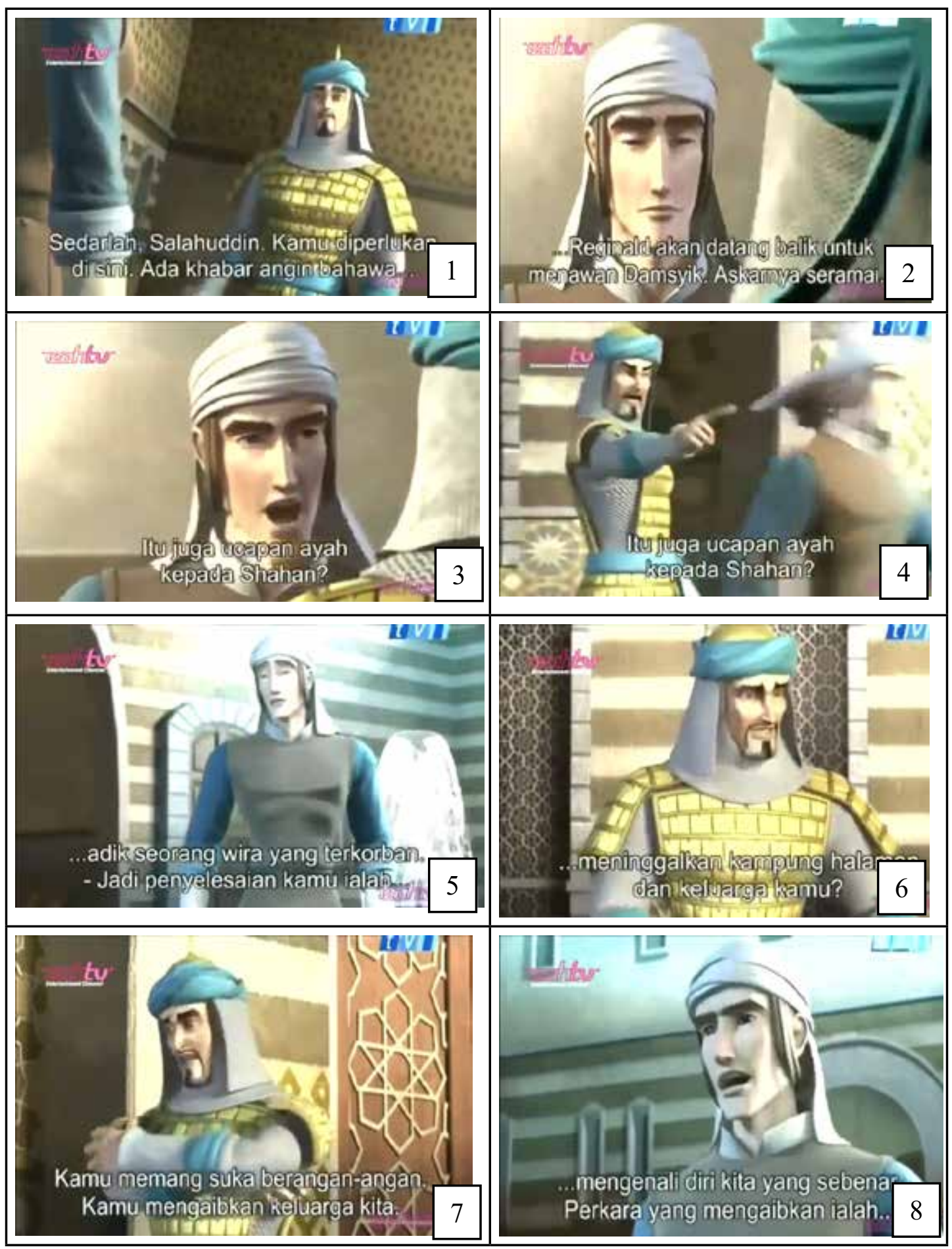




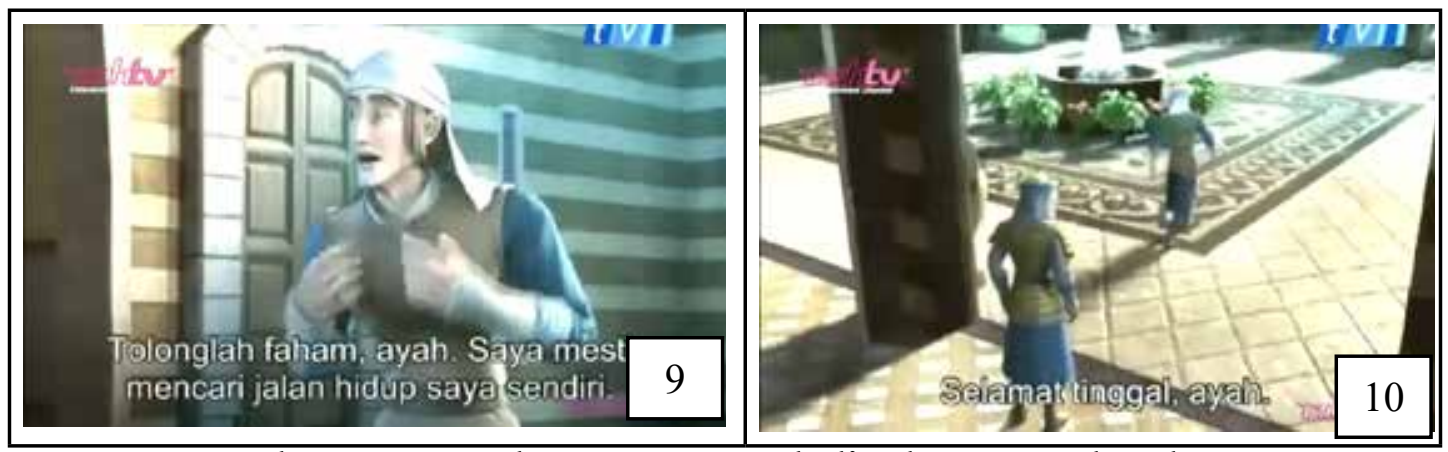

Gambar 5: Pertengkaran antara Saladin dengan ayahandanya

(12:16 - 13:16 di Animated_Stories_of_Islam.nashbooky.com.mp4)

Bingkai kedua menunjukkan Saladin yang bersedih apabila diminta oleh bapanya, Ayyub untuk kekal berada di Damsyik dan ikut sama berperang seperti bapa dan arwah abangnya Shahan. Shahan terkorban dalam peperangan menentang tentera Reginald sewaktu dia berumur lapan tahun. Pada Saladin, bapanya sentiasa mengongkongnya dalam membuat keputusan. Menurut bapanya, Reginald akan menyerang Damsyik kembali dengan membawa tentera yang lebih ramai, dan Sultan serta penduduk Damsyik memerlukan Saladin. Katakata tersebut telah membuatkan Saladin marah dan berkata bahawa bapanya menggunakan ucapan yang sama kepada Shahan sehingga Shahan menurutinya ke medan perang dan terkorban. Bapanya memarahinya dengan menyatakan bahawa Shahan syahid sebagai seorang pejuang. Justeru, kata-kata Saladin telah membuatkan Ayyub marah lalu mengatakan bahawa Saladin serorang anak yang tidak mengenang budi.

Saladin memberitahu bahawa dia perlu mengembara dan meninggalkan keluarga, masyarakat, dan rajanya untuk membaiki dirinya sendiri. Menurut Saladin, dia akan sentiasa dinilai sebagai adik kepada pejuang yang terkorban dan tidak lebih daripada itu. Perkara ini tidak disenangi oleh bapanya, lalu Saladin dituduh seorang yang suka berangan dan mengaibkan keluarga. Saladin tidak bersetuju, lalu menyatakan bahawa tidak salah untuk dia mengenali diri sendiri. Dia meminta bapanya untuk melepaskan dirinya pergi bagi mencari jalan hidupnya sendiri, dan akhirnya, Saladin memilih untuk meninggalkan bapanya.

Serangan Orientalisme dalam babak di atas adalah dari segi sikap Saladin yang tidak mentaati kata-kata Ayyub, bapanya. Perkara ini sangat bertentangan dengan sifat Salahuddin al-Ayubi kerana Salahuddin ialah seorang yang sangat mentaati bapanya. Sewaktu Sultan Salahuddin menjadi pemerintah Mesir, berlaku penaklukan beberapa wilayah dalam usaha untuk menyatukan umat Islam dalam memenangi kembali Baitul Muqaddis. Walaupun Sultan Salahuddin mempunyai kekuatan tentera yang besar, baginda tetap mentaati bapanya untuk tidak menyerang atau membalas serangan Nuruddin Zanki, penguasa Syria dan beberapa kawasan yang lain (Beha Ed-Din, 1896 : 61-65; \& Dr. Mahmud, 1998).

Nuruddin Zanki merupakan sahabat ayahandanya, Najmuddin Ayyub. Ayyub pernah membantu ayahanda Nuruddin Zanki, iaitu Immaduddin Zanki, dengan memberikan perlindungan sewaktu peperangan menentang Iraq untuk membebaskan kaum Seljuk dan membantunya melepaskan diri melalui Tikrit. Selepas diketahui pemerintah, jawatan Ayyub dan Shirkuh (bapa saudara Salahuddin) dilucutkan dan mereka diperintahkan meninggalkan Tikrit serta-merta. Setelah sampai di Mosul, Ayyub dan keluarganya disambut oleh Imaduddin Zanki. Ayyub dilantik sebagai penguasa selepas Ba'albek berjaya ditawan oleh 
Zanki manakala Shirkuh dilantik menjadi ketua perang (Syed Alwi, 2015:11-15). Disebabkan keakraban persahabatan Ayyub dan Imaduddin Zanki, permintaan bapanya untuk tidak menyerang dan menakluk Aleppo yang berada di bawah pemerintahan Nuruddin Zanki dituruti oleh Salahuddin. Malahan, Salahuddin menuruti pemintaan Nuruddin Zanki dalam beberapa siri peperangan.

Salahuddin al-Ayubi patuh kepada permintaan bapanya untuk tidak menyerang Nuruddin sehinggalah kewafatan Nuruddin Zanki pada 1174 (Syed Alwi, 2015: v). Selepas kewafatan Nuruddin, barulah Salahuddin meluaskan daerah kekuasaannya ke Mesir, sebahagian daripada Syam, al-Jazirah, Yaman dan Mosul (Mohd Roslan \& Nor Shakila, 2012:69). Daulah Ayyubiyah telah tersebar luas ke kawasan dunia Arab. Sebaliknya, penyelewengan orientalis telah mengubah perwatakan Sultan Salahuddin al-Ayubi dengan menggambarkan baginda tidak mentaati bapanya, dan ini memberi imej buruk pada persepsi golongan remaja dan kanak-kanak yang menonton Saladin: The Animated Series.

\section{Ibu dan bapa: Restu ketika Azan Berkumandang}

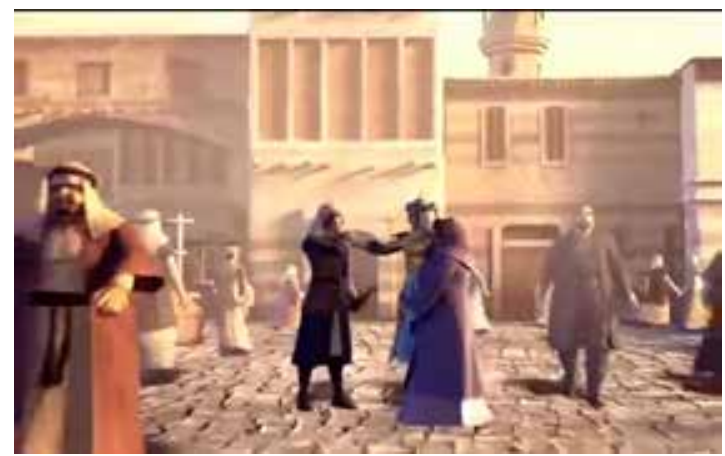

Gambar 6: Ibu dan ayah Saladin mengucapkan selamat jalan di saat azan berkumandang

(24:22 di Animated_Stories_of_Islam.nashbooky.com.mp4)

Dalam babak daripada episod kedua, Salahuddin mendapat restu daripada kedua-dua ibu dan bapanya untuk mengembara bersama Tarik dengan menyertai kumpulan dagang Tuan Mustafa. Ketika azan berkumandang, Salahuddin tidak mengendahkannya, dan begitu juga bapa dan ibunya, malahan Salahuddin meneruskan perjalannya bersama Kabilah Mustafa. Babak ini merupakan suatu penyelewengan terhadap perwatakan Salahuddin kerana dalam kehidupan sebenar, Salahuddin tidak meninggalkan solat berjemaah walaupun ketika baginda sakit. Apabila baginda jatuh sakit, imam dijemput ke rumah baginda untuk diimami malahan baginda berusaha untuk berdiri walaupun dalam keadaan sakit (Beha Ed-Din, 1896: 7).

\section{Saladin: Mengungkit dan Mengugut}

Babak ini bermula dengan Anisa yang pada mulanya telah bekerjasama dengan Darwish untuk mencuri Delima Merah yang diberi nama Bintang Parsi atau Pearl of Persia daripada Tuan Mustafa, majikan Darwish. Namun begitu, Saladin dan Tarik terlebih dahulu mengetahui rancangan mereka lalu cuba menyekat mereka daripada mencuri permata yang paling besar di seluruh Tanah Arab itu. Setelah itu, berlaku kejadian di luar jangkaan 
apabila Darwish bukan sahaja mengkhianati Tuan Mustafa, malahan mengkhianati Anisa. Pada bingkai kedua, Darwish telah mengikat Tuan Mustafa, Anisa, Saladin dan Tarik, dan membakar gudang bersama-sama mereka untuk menutup bukti.
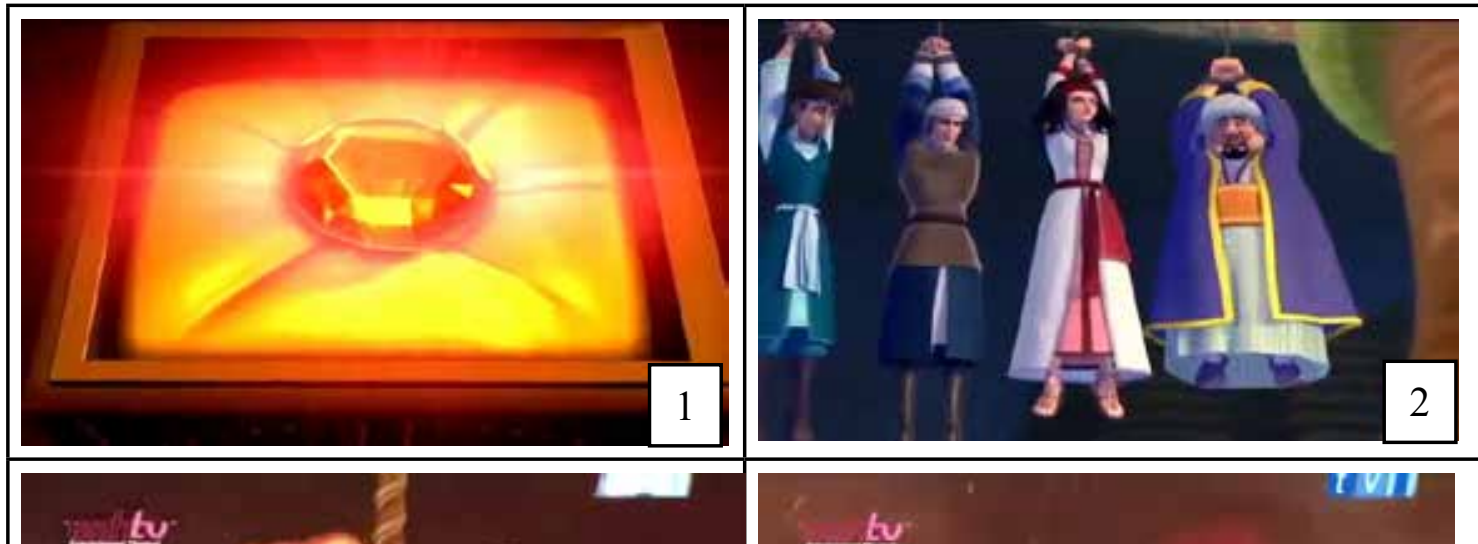

IVII

ty

Kerja untuk dua orange bodch seperti kamu? Kamu seperti.
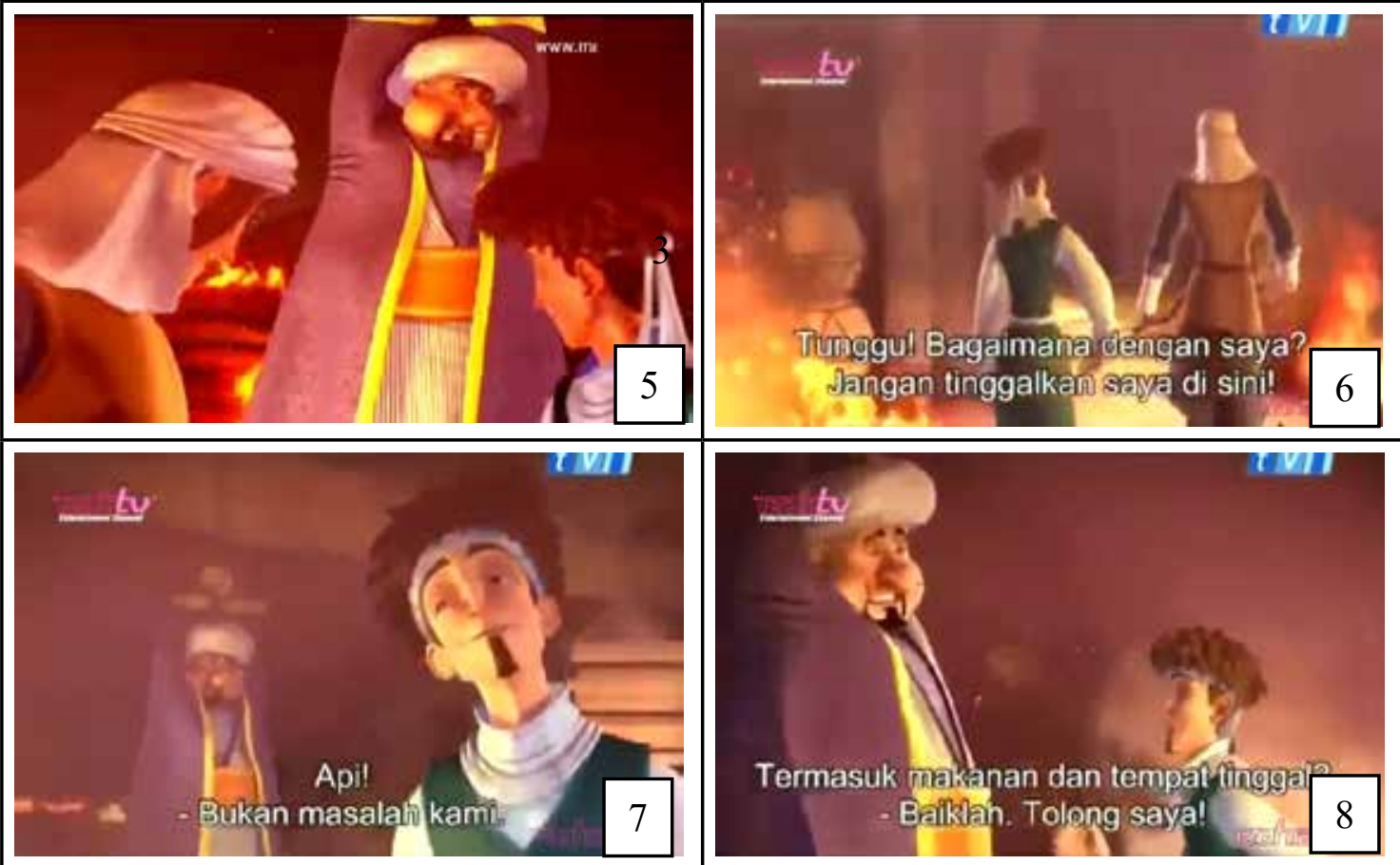

Gambar 7: Saladin, Tarik, Anisa dan Tuan Mustafa

(19:27-20:17, 21:49-21:52 di Animated_Stories_of_Islam.nashbooky.com.mp4) 
Babak ini menunjukkan kebijaksanaan Anisa yang menyimpan pisau (bingkai ketiga), sehingga dia berjaya melepaskan dirinya. Sewaktu berjalan keluar pada bingkai keempat, Anisa telah dihentikan oleh Saladin. Saladin berkata bahawa Anisa masih berhutang budi dengannya, kerana Saladin pernah menyelamatkan Anisa semasa melarikan diri daripada penjual roti sewaktu kecil (Anisa ditangkap oleh penjual roti sewaktu mencuri rotinya). Penjual roti telah menangkap dan ingin membawa Anisa ke muka pengadilan yang boleh mengakibatkannya dipotong tangan kerana mencuri. Anisa telah menggigit tangan penjual roti dan melarikan diri dan bersembunyi di tempat Saladin sedang bermain pedang dengan Tarik. Penjual roti ternampak Anisa yang sedang bersembunyi di sebalik tong kayu tetapi Saladin telah menarik tangan Anisa dan melarikan diri. Oleh sebab Saladin telah membangkitkan 'hutang budi', Anisa telah membantunya untuk melepaskan diri daripada kebakaran di gudang yang dicetuskan oleh Darwish. Setelah itu, Anisa berlalu untuk menjejaki Darwish. Perlecehan peribadi Salahuddin terlihat pada sikapnya yang bergantung harap pada seorang wanita untuk menyelamatkan dirinya sedangkan hakikatnya Salahuddin tidaklah selemah itu.

Perbuatan Saladin mengungkit pertolongan yang pernah diberikan kepada Anisa sewaktu kecil dan menuntut Anisa untuk membalasnya kembali juga merupakan perlecehan peribadi Salahuddin. Menurut ajaran Islam, mengungkit perkara kebaikan yang pernah dilakukan akan memusnahkan pahala kebaikan tersebut. Dalam al-Quran surah al-Baqarah ayat 264 Allah berfirman yang mafhumnya: "Hai orang-orang yang beriman, janganlah kamu menghilangkan (pahala) sedekahmu dengan menyebut-nyebutnya dan menyakiti (perasaan si penerima)."

Selepas menyelamatkan dirinya, Saladin menyelamatkan Tarik yang masih terikat. Dalam bingkai kelima, Tuan Mustafa masih tergantung dan terikat serta tidak dilepaskan kerana pada awalnya, Tuan Mustafa telah menolak permintaan Tarik dan Saladin untuk bekerja dengannya sebagai pengawal kafilah ke Mesir serta pembawa barangan dagangan. Dalam bingkai keenam, ketujuh dan kelapan, sebagai balasan untuk melepaskan Tuan Mustafa, mereka harus diterima bekerja sebagai pengawal kafilah dengan 10 wang perak seminggu, berserta makanan dan tempat tinggal. Dalam babak ini seolah-olah Saladin mengugut Tuan Mustafa untuk mendapat pekerjaan. Tuan Mustafa tiada pilihan selain menerima tawaran Saladin dan Tarik kerana itu dapat menyelamatkan nyawanya.

\section{Saladin Tumpas di Tangan Anisa}

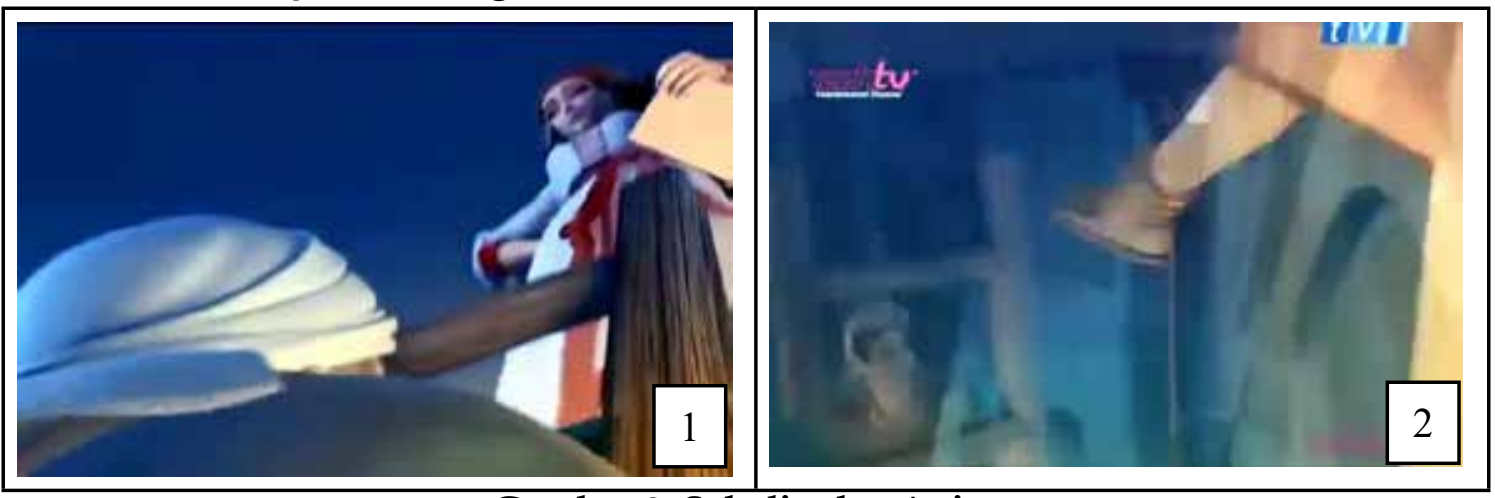

Gambar 8: Saladin dan Anisa

(21:50 - 22:04 di Animated_Stories_of_Islam.nashbooky.com.mp4) 
Gambar 8 memaparkan adegan selepas berlakunya pergaduhan antara Saladin dengan Darwish. Ketika itulah Anisa datang dan membawa lari kotak yang berisi Star of Persia. Saladin mengejar Anisa tetapi Anisa berjaya memanjat tembok bangunan dengan mudah. Saladin pula terpaksa menggunakan tangga kerana tiada kemampuan untuk memanjat tembok bangunan. Sewaktu Saladin memanjat tangga, Anisa sudah menunggunya di atas. Anisa yang berpakaian ala gipsi dan berkain sedikit pendek, telah menolak tangga yang dipanjat oleh Saladin dengan kakinya.

Serangan orientalis terhadap kredibiliti Saladin dalam babak ini adalah apabila Saladin memandang Anisa yang berada di atas bangunan. Orientalis telah meletakkan wanita lebih tinggi daripada tokoh pejuang Islam ini. Salahuddin diletakkan di bawah kaki wanita yang kemudiannya ditolak dengan kaki.

Bagi masyarakat Melayu, Cina mahupun India di Malaysia, penggunaan kaki terhadap orang lain adalah perlakuan yang sangat buruk apatah lagi cerita tentang seorang pejuang yang akhirnya menjadi raja. Sekiranya cerita ini ditulis di Malaysia oleh penulis tempatan walau apa jua bangsanya, penggunaan kaki oleh kaum wanita terhadap lelaki dilarang kerana perbuatan tersebut menunjukkan kelakuan biadap dan tidak menghormati orang lain. Inikan pula watak Saladin ini adalah representasi Salahuddin al-Ayubi, Sultan Mesir, tokoh pejuang Islam yang membebaskan Palestin daripada pasukan Salib. Sepatutnya babak yang menghina atau bingkai seperti ini tidak diwujudkan walaupun dalam siri animasi.

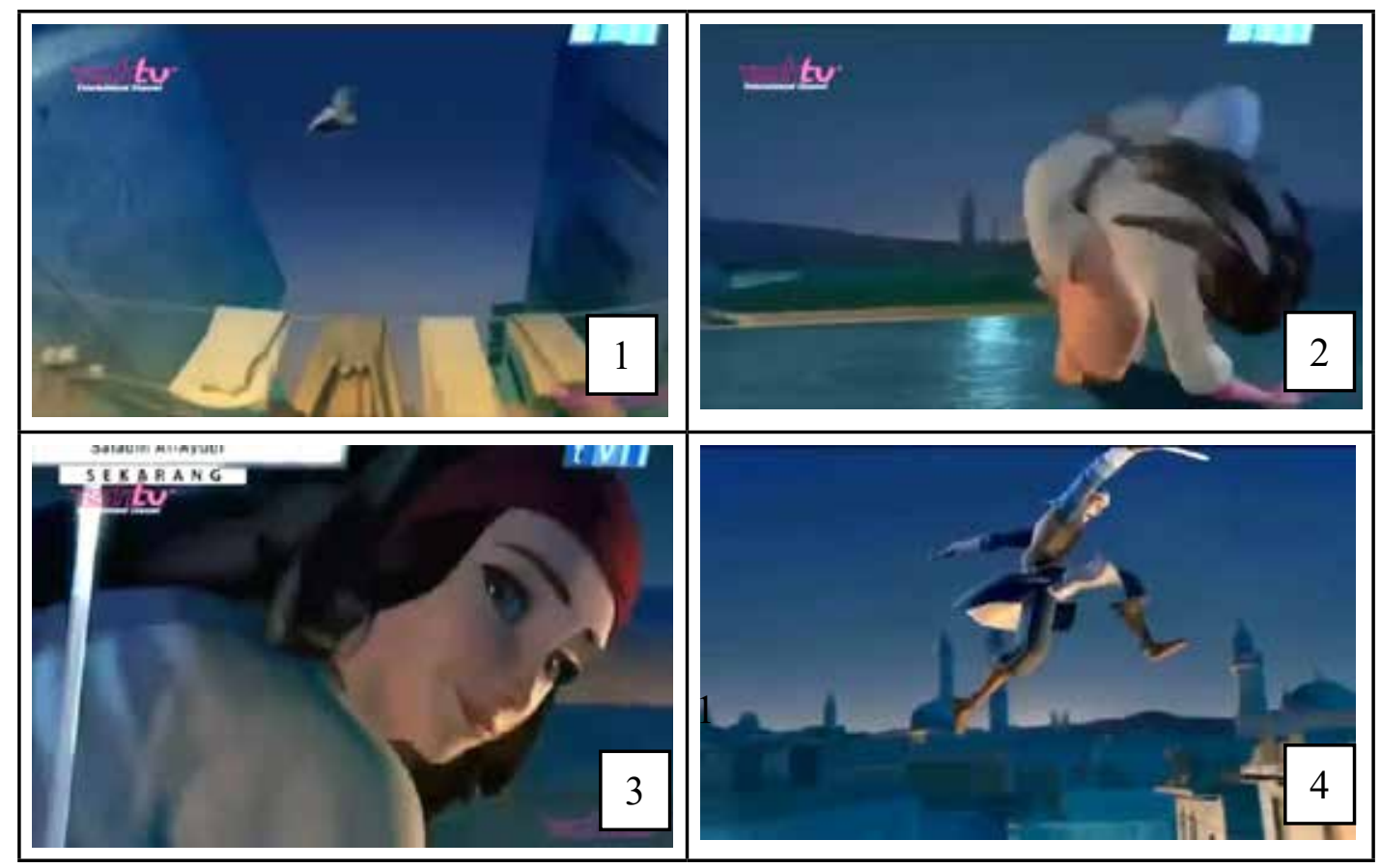




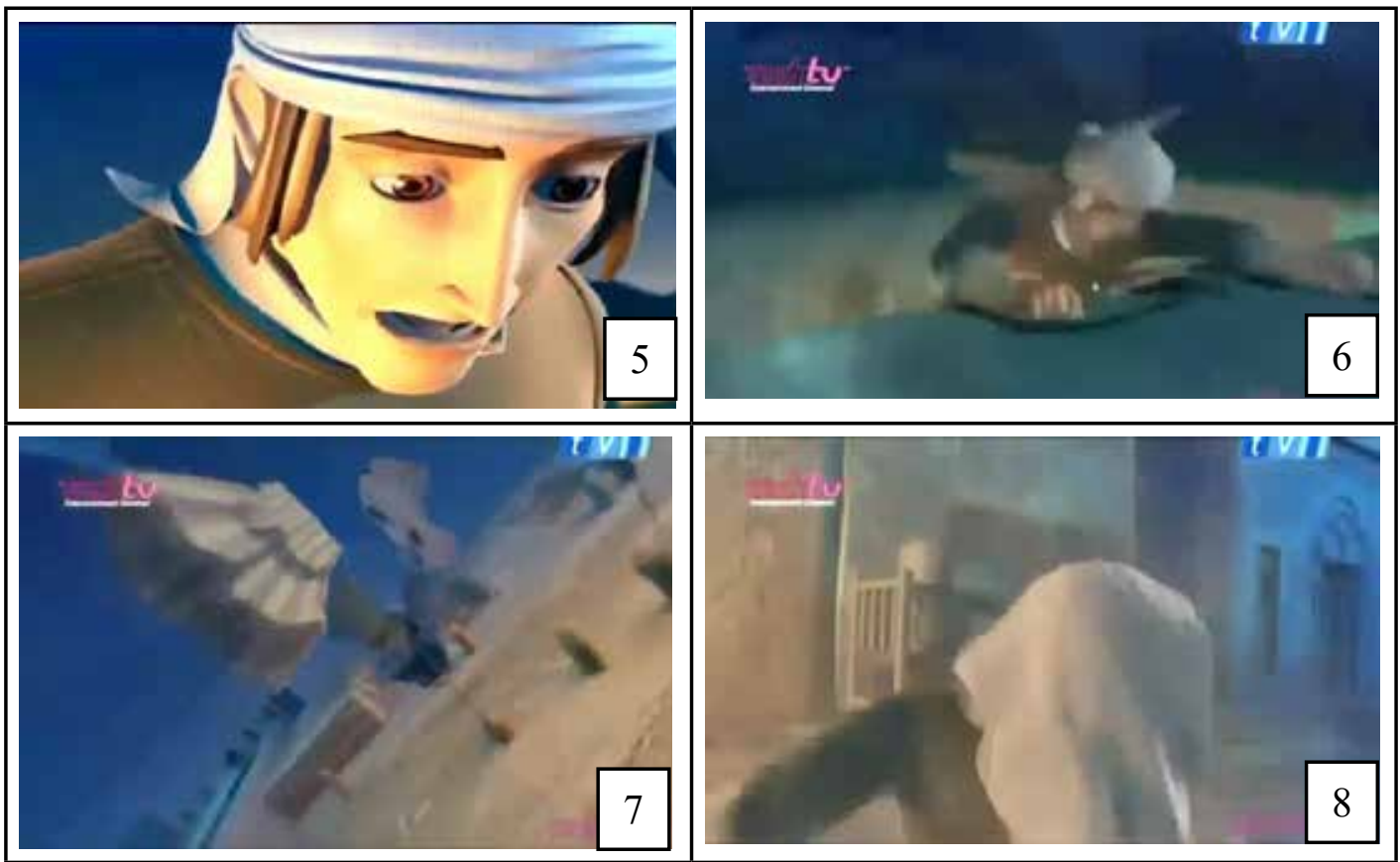

Gambar 9: Saladin dan Anisa

(22:05 - 22:24 di Animated_Stories_of_Islam.nashbooky.com.mp4)

Lapan bingkai di atas berlaku ketika Saladin mengejar Anisa yang cuba membawa lari delima merah Star of Persia. Bingkai pertama menunjukkan Anisa terlebih dahulu melompat dari bangunan pertama. Bingkai kedua, Anisa berjaya mendarat dengan baik di bangunan yang kedua. Bingkai ketiga, dia lalu menoleh ke arah Saladin yang masih mengejarnya dengan wajah yakin bahawa Saladin tidak mampu melakukannya. Kemudian, bingkai ke empat menunjukkan Saladin melompat dari bangunan yang sama. Namun begitu, dalam bingkai yang keenam, dia tidak berjaya mendarat dengan baik di bangunan yang kedua. Dalam bingkai ketujuh dan kelapan, Saladin terjatuh ke bawah bangunan, yang menandakan ketewasannya.

Wacana orientalisme dalam babak ini menunjukkan kelemahan Saladin yang tidak mampu walaupun hanya untuk melompat dari satu bangunan ke bangunan yang lain. Sebaliknya walaupun Anisa seorang wanita, dia berjaya melompat sehingga melepasi bangunan. Pemalsuan pihak orientalis untuk menunjukkan kelemahan fizikal Salahuddin seorang tokoh Islam yang terkenal dengan kegagahan fizikalnya dalam siri peperangan yang disertainya.

\section{KESIMPULAN}

Dalam Saladin: The Animated Series, walaupun hampir keseluruhan tenaga kerjanya daripada Malaysia, pengarah yang menjana idea dan mengawal keseluruhan konsep bagi siri animasi dan trailer filem animasi tersebut ialah orientalis, Steve Bristow yang berasal dari Australia. Bristow juga memainkan peranan besar dalam kelahiran siri animasi yang dikeluarkan oleh negara ini. Antara penyelewengan yang dilakukannya ialah pemaparan peribadi Salahuddin al-Ayubi melalui watak Saladin yang jauh tersasar daripada peribadi sebenar tokoh itu. 
Kisah hidup yang dilalui pada zaman kanak-kanak dan remaja tokoh itu telah ditukar oleh pengarahnya yang berasal dari luar ini dengan membentuk jalura kehidupan yang baharu.

Penyelewengan ini berlaku bagi "menyerang" semula bakti yang telah ditaburkan oleh Sultan Salahudin kepada masyarakat Palestin, Mesir dan lebih-lebih lagi pihak Kristian dalam Perang Salib. Salahuddin al-Ayubi ialah tokoh Islam yang berjaya memenangi kembali Baitul Maqdis tanpa peperangan (Mohd Roslan \& Nor Shakila, 2012). Ini telah memberi tamparan yang sangat hebat kepada pihak gereja di London pada ketika itu.

Perang Salib memakan masa yang lama, iaitu dari tahun 1096 sehingga 1291 Masihi dengan tujuh siri peperangan (Mohd Roslan \& Nor Shakila, 2012: 62). Salahuddin al-Ayubi ialah panglima yang paling banyak memimpin gerakan tentera Islam dalam memerangi tentera Salib. Kenyataan ini tidak menggembirakan hati pihak orientalis, lalu mereka menggunakan pelbagai cara untuk merendah-rendahkan tokoh pahlawan ini. Sekiranya mereka tidak berjaya mengubah sejarah kemenangan pihak Islam ke atas Jerussalem dan ketokohan Sultan Salahuddin al-Ayubi, cara jalan yang halus untuk menjatuhkan kredibiliti Salahuddin al-Ayubi adalah melalui waktu zaman mudanya; zaman kanak-kanak, dan zaman remajanya. Ini yang berjaya dilakukan oleh pihak produksi Saladin the Animated Series. Saladin yang ditampilkan oleh pihak produksi bukan peribadi Sultan Salahuddin alAyubi tetapi mereka telah membentuk suatu sifat dan sikap seorang Saladin yang baharu.

Antara fitnah Barat terhadap Islam adalah dengan menggambarkan orang Islam sebagai penjahat. Dalam konteks perbincangan Orientalisme, dunia Timur dan dunia Islam khususnya, tidak bertamadun dan terkebelakang. Maka, orientalis berpendapat mereka perlu mentamadunkan orang Timur dengan cara penjajahan (Said, 1978: 207). Antara usaha untuk mentamadunkan orang Timur kini adalah dengan cara penjajahan minda. Menurut Nilan (2008) dalam artikel Muslim Media and Youth in Globalizing Southeast Asia, sasaran penonton bagi Saladin: The Animated Series ialah kanak-kanak Islam di seluruh dunia yang berumur 10 hingga 12 tahun. Siri ini juga memaparkan aksi perang epik untuk menarik minat kanak-kanak Islam khususnya (Nilan, 2008). Maka, golongan ini akan terkesan dengan penyelewengan yang dilakukan oleh pihak produksi Saladin: The Animated Series melalui perubahan pada kehidupan Salahuddin semasa zaman remajanya.

Selaku pengarah, Steve Bristow seharusnya menggunakan kepakaran dan pengalamannya untuk menghasilkan siri animasi biografi tokoh agung umat Islam, Salahuddin al-Ayubi sebagaimana yang telah dicatat oleh Baha ed-Din yang merupakan mufti pada zaman Salahuddin. Cerita ini mengambil latar sejarah yang diilhamkan daripada kisah sejarah panglima agung Islam, Salahuddin al-Ayubi yang berjaya menentang tentera Kristian dalam Perang Salib ketiga pada abad ke-12 dan membina empayar Islam serta menyatupadukan umat Islam seluruhnya. Namun begitu, wacana orientalisme yang dihasilkan oleh Steve Bristow merosakkan imej Salahuddin al-Ayubi dengan penyelewengan fakta dan perlecehan peribadi.

\section{RUJUKAN \\ Buku}

Amin Sweeney. (1972). Malay Shadow Puppets: The Wayang Siam of Kelantan. London. British Museum.

Ashcroft, B., Griffiths, G., \& Triffin, H. (1989). The empire writes back: theory and practice in post-colonial literatures. London: Routledge. 
Halas, J., \& Manvell, R. (1970). The technique of film animation . London: Focal Press. Hassan Mutalib. (2008). Sejarah perkembangan animasi tempatan. Kuala Lumpur: ASWARA Imam Al Ghazali. (2009). Ihya' Ulumuddin. Jakarta: Akbar Media.

Lane-Poole, S. (1906). Saladin and the fall of the Kingdom of Jerusalam. London: G.P. Putnam's Sons.

Mohd Taib Osman. (1989). Malay folk beliefs: an integration of disparate elements . Kuala Lumpur: Dewan Bahasa dan Pustaka.

Muhammad Fu'ad Abdul Baqi. (2017). Kumpulan Hadits Shahih Bukhari-Muslim. Jawa Tengah: Insan Kamil.

Norizan Esa, Leela Rajamani, \& Zuraidah Mohd. Yusuf. (2014). Reengineering local knowledge: life science and technology. Pulau Pinang: USM Press.

Sami Abdullah Al-Maghlus. (2015). Altas Perang Salib: Sejarah berdarah menyayat hati. Kuala Lumpur: Publishing House Sdn Bhd.

Said, Edward. (1978). Orientalism: Western conception of the Orient. London: Penguin Group. Said, Edward. (1983). The world, the text and the critic. London: Cambridge, Mass: Harvard University Press .

Mahmud Syalabi. (1998). Salahuddin Al-Ayyubi: Pahlawan Perang Salib (terjemahan dari Arab). Kuala Lumpur: Visi Madani.

Syed Alwi Alatas. (2015). Biografi agung Nuruddin Zanki. Shah Alam: Karya Bestari, Grup Buku Karangkraf Sdn. Bhd.

Syed Alwi Alatas. (2015). Biografi agung Salahuddin Al Ayyubi. Shah Alam: Karangkraf.

Yusuf Al Qaradhawi. (2016). Halal dan haram dalam Islam. Gombak: PTS Publishing House.

Zawiah Yahya. (2003). Resisting colonialist discourse. Bangi: Universiti Kebangsaan Malaysia.

\section{Internet}

Abdul Aziz Itar. (2011, 3 Januari). Saladin ditayangkan di 20 negara. Utusan Online. Dimuat turun 20 Disember 2014, daripada Utusan.com.my: http://www.utusan.com.my

Bristow, S. (2013). Steve Bristow: Producer, director, manager. Dimuat turun pada 3 Disember 2015, daripada Steve Bristow: http://www.stevebristow.com/

Saladin Animated Stories of Islam. (04 Sept, 2013). Dimuat turun daripada Youtube NasbookyAnime: https://www.youtube.com/watch?v=xy02s91Jtgw

Saladin Filem Animasi Malaysia. (28 Mac, 2007). Dimuat turun 13 Oktober, 2014, daripada http://www.utusan.com.my

Wayang Kulit.http://courses.ncssm.edu/gallery/collections/toys/html/exhibit06.htm

\section{Jurnal}

Imam Hendra Saputra. (2015). Orientalisme kolonial dalam kisah pertualangan mowgli dalam novel The Jungle Book karya Rudyard Kipling: Tinjauan Pascakolonialisme. Jurnal Lingua Idea. 6 (1), 1-11.

Mohd Roslan Mohd. Nor, \& Nor Shakila Mohd. Noor. (2012). Perang Salib dan kejayaan Salahuddin Al Ayubi mengembalikan Islamic Jerusalem kepada umat Islam. Jurnal AlTamaddun. 7 (1), 61-74. 
Mohd Roslan Mohd. Nor, \& Nor Shakila Mohd Noor. (2012). Salahuddin Al Ayubi dalam menangani masyarakat Kristian di Islamic Jerusalem dan Palestin. Jurnal Usuluddin, 35, 81-98.

Nilan, P. (2008). Muslim media and youth in globalizing Southeast Asia. Dlm. Y. Kim, Media consumption and everyday life in Asia (hlm. 45-58). Madison Ave, New York: Routledge.

Paizah Haji Ismail. (2008). Kaedah pembuktian dalam kes hudud. Jurnal Figh, 5, 23-46.

Rentse, A. (1936). The Kelantan shadow-play (wayang kulit). Journal of the Malayan Branch of the Royal Asiatic Society, 14 (3), 284-301.

Syamila Syamim Mohd. Yatim. (2016). Akhlak dan pembangunan insan: Pemikiran pendidikan Islam menurut Imam Al-Ghazali. Seminar Antarabangsa Pemerkasaan Pendidikan Islam (pp. 10-20). Kuala Lumpur: University Malaya Press.

\section{Tesis}

Mohamad Aminudin. (1988). Jihad: suatu kajian mengenai konsep dan penghayatan masakini di Malaysia. Tesis PhD. Fakulti Usuluddin, Akademi Islam Universiti Malaya.

Fauzia Hazmi. (2007). Representasi Orientalisme dalam Flim: Analisis Semiotik Mengenai Representasi Orientalisme dalam film Black Hawk Down. Tesis Sarjana. Fakultas Ilmu Sosial dan Ilmu Politik, Universitas Airlangga, Surabaya.

\section{Filem/Animasi}

Bristow, S. (Director). (September 2010). Saladin: The Animated Series [Motion Picture]. 